\title{
OVERVIEW: FAKTOR PENDORONG TERJADINYA KETERKAITAN KOTA- DESA DARI SEGI PERGERAKAN ORANG ANTARA KOTA MOJOKERTO DENGAN WILAYAH PERI-URBAN DI KABUPATEN MOJOKERTO
}

\author{
Belinda Ulfa Aulia ${ }^{1}$ \\ 1Departemen Perencanaan Wilayah dan Kota, Institut Teknologi Sepuluh Nopember
}

\begin{abstract}
Abstrak
Kota Mojokerto sebagai wilayah perkotaan yang memiliki kelengkapan fasilitas pelayanan sedangkan Kabupaten Mojokerto yang memiliki potensi dalam bidang pertanian dan perindustrian. Masyarakat melakukan pergerakan hingga keluar dari wilayah tempat tinggalnya, yaitu pergerakan dari desa ke kota maupun sebaliknya untuk memenuhi kebutuhannya. Hal ini menyebabkan beberapa masalah mulai bermunculan. Salah satunya terjadi kepadatan volume kendaraan pada beberapa ruas jalan. Penelitian ini memiliki tujuan untuk mengidentifkasi faktor-faktor pendorong terjadinya keterkaitan kota-desa antara Kota Mojokerto dengan wilayah periurban di Kabupaten Mojokerto. Faktor-faktor tersebut dapat digunakan dalam perumusan arahan dalam program pembangunan terkait pola pergerakan penduduk dari desa ke kota dan dari kota ke desa yang terjadi secara masif maupun tidak masif. Pada penelitian ini digunakan analisis klaster JMP untuk mengetahui faktor-faktor yang mendorong terjadinya keterkaitan kota-desa antara Kota Mojokerto dengan wilayah peri-urban di Kabupaten Mojokerto. Dari analisis tersebut, dapat diketahui bahwa terdapat beberapa faktor yang menjadi pendorong keterkaitan kota-desa dalam konteks pergerakan orang. Faktor yang mendorong pergerakan orang dari desa ke kota adalah keinginan masyarakat untuk mencari hiburan/rekreasi; ketersediaan fasilitas perbelanjaan atau rekreasi; kualitas pelayanan sarana; adanya peluang usaha; biaya hidup yang rendah; dan kemudahan menjangkau sarana. Sedangkan untuk faktor yang mendorong terjadinya pergerakan manusia dari kota ke desa adalah kualitas pelayanan sarana; biaya hidup yang rendah; keinginan masyarakat utnuk mencari hiburan; ketersediaan fasilitas perbelanjaan atau rekreasi; adanya relasi/hubungan sosial; adanya peluang usaha; dan kemudahan menjangkau sarana. Faktor-faktor tersebut secara general termasuk dalam hubungan sosial ekonomi.
\end{abstract}

Kata kunci: keterkaitan kota-desa; pergerakan orang; wilayah peri-urban

\begin{abstract}
Mojokerto City is an urban area that has complete service facilities while Mojokerto Regency has potential in agriculture and industr. The community living in the peri-urban area commutesfrom the village to the city to meet their needs, a nd vice versa. This commuting pattern causes several problems, such as road density. This study aims at identifying the driving factors for the occurrence of urban-village linkages between Mojokerto City and peri-urban areas in Mojokerto Regency. These factors can be used to formulate the policy for in development programs related to the pattern of population's daily movement from villages to cities and from cities to villages. In this study, JMP cluster analysis is selected to determine the factors that drive the linkages between cities and villages between Mojokerto City and peri-urban areas in Mojokerto Regency. The results show thatthere are a number of factors that have driven urban-rural linkage in the context of the commuting. The driving factors are people's desire to seek for entertainment / recreation; availability of shopping or recreation facilities; quality of service facilities; there are business opportunities; low cost of living; and ease of reaching facilities. Whereas the factors that encourage the movement of people from cities to villages are the quality of service facilities; low cost of living; people's desire to seek entertainment; availability of shopping or recreation facilities; existence of relations / social relations; there are business opportunities; and ease of reaching facilities. These factors are generally included in socio-economic relations.
\end{abstract}

Keywords: people flow; peri-urban areas; urban-village linkages

\section{PENDAHULUAN}

Setiap wilayah mempunyai sumber daya tertentu untuk memenuhi kebutuhan hidup manusia, namun apabila sumber daya tidak tersedia manusia akan memenuhinya dari wilayah lain yang memiliki sumber daya yang diperlukan. Dengan demikian antar wilayah terjadi hubungan dalam kaitan pemenuhan kebutuhan hidup manusia di dalamnya. Mike Douglas (1998) dalam Kasikoen (2011) menggambarkan keterkaitan kota dan desa dalam bentuk saling ketergantungan, 
bukannya hubungan satu arah kota ke desa atau desa ke kota. Keterkaitan kota-desa dapat dilihat sebagai sama-sama saling memperkuat (mutually reinforcing). Hal ini sesuai yang dinyatakan oleh Kasikoen (2005) bahwa keterkaitan perkotaan - perdesaan dapat berupa keterkaitan yang saling mendukung (komplementer) atau eksploitatif.

Berdasarkan RTRW Kota Mojokerto tahun 2012 - 2032, Kota Mojokerto memiliki beberapa pusat kegiatan yang dapat manarik pergerakan memusat pada Kota Mojokerto. Dari segi regional, di Kota Mojokerto terdapat pusat pemerintahan skala kabupaten serta beberapa kantor instansi pemerintahan. Selain itu Kota Mojokerto juga memiliki fasilitas perkotaan seperti fasilitas kesehatan, fasilitas pendidikan, serta fasilitas perdagangan dan jasa. Berdasarkan fakta tersebut, Kota Mojokerto dapat dikatakan sebagai pusat kegiatan dan pelayan publik Kabupaten Mojokerto, terutama bagi wilayah yang berbatasan langsung dengan Kota Mojokerto. Hal ini memicu adanya pergerakan orang yang cenderung memusat. Pergerakan ini dipengaruhi adanya tarikan yang dihasilkan oleh Kota Mojokerto serta adanya dorongan dari masyarakat untuk memenuhi kebutuhan pelayanan dan kegiatan lainnya di pusat kota.

Menurut RTRW Provinsi Jawa Timur Tahun 2011 - 2031 Kabupaten Mojokerto merupakan salah satu wilayah yang memiliki keunggulan dalam sektor pertanian yang menjadi pemasok hasil pertanian ke wilayah sekitarnya termasuk Kota Mojokerto. Selain itu Kabupaten Mojokerto juga memiliki keunggulan dalam sektor industri yang dapat menimbulkan aliran barang dan orang dengan wilayah sekitarnya termasuk Kota Mojokerto. Hal ini mengakibatkan secara tidak langsung muncul interaksi atau keterkaitan yang terbentuk antara Kabupaten Mojokerto dengan Kota Mojokerto.

Pada dasarnya, aliran dapat dibedakan menjadi dua tipe. Tipe pertama yaitu spasial, termasuk di dalamnya adalah aliran orang, barang, uang, teknologi, ilmu pengetahuan, informasi dan limbah/pembuangan. Dalam perspektif biofisik, aliran air, produk tanaman organik, dan bahan gizi juga termasuk dalam tipe spasial. Sedangkan tipe kedua adalah sektoral, yang di dalamnya adalah aliran produk pertanian menuju ke wilayah urban dan peri-urban, serta barang dari wilayah urban manufacturing menuju ke wilayah yang lebih rural (Tacoli, 1998 dalam Braun, 2007). Kedua tipe aliran tersebut dapat bergerak secara terus menerus/kontinyu baik dari wilayah desa ke kota maupun dari kota ke desa. Pergerakan aliran tersebut menimbulkan terjadinya keterkaitan kota-desa. Interaksi ataupun keterkaitan wilayah kotadesa ini dapat dikatakan sebagai hubungan timbal balik antar wilayah yang dapat terbentuk karena adanya hubungan yang saling mengisi (complementarity), perpindahan manusia atau barang (transferability), serta akibat dari faktor penghambat (intervening opportunity) (Kasikoen, 2011).

Untuk memenuhi kebutuhannya, masyarakat Kabupaten Mojokerto cenderung bergerak memusat pada Kota Mojokerto dan sekitarnya yang merupakan pusat kegiatan dan pelayan publik. Sedangkan untuk memenuhi kebutuhan lain seperti permukiman, pangan, barang produksi manufaktur, wisata dan kebutuhan lainnya, aliran spasial maupun sektor lebih cenderung ke arah wilayah yang lebih rural. Pergerakan aliran tersebut memunculkan interaksi antara kotadesa sehingga terbentuk kerterkaitan antara Kota Mojokerto dengan wilayah-wilayah di Kabupaten Mojokerto berpengaruh pada perkembangan wilayah peri-urban atau pinggiran kota.

Keterkaitan kota-desa akibat dari pergerakan orang yang terjadi antara Kota Mojokerto dengan Kabupaten Mojokerto sebagai wilayah peri-urban menimbulkan banyak dampak. Salah satu dampak yang terjadi adalah kemacetan di beberapa titik jalan penghubung antara Kota Mojokerto dan Kabupatan Mojokerto. Pada waktu tertentu terjadi adanya penaikan volume kendaraan karena adanya pergerakan secara masif masyarakat Kota Mojokerto dan Kabupaten Mojokerto yang melakukan pergerakan dari Kota Mojokerto ke Kabupaten Mojokerto maupun sebaliknya. Untuk meminimalisir dampak yang terjadi, perlu adanya penanganan dan solusi yang tepat. Dengan mengetahui faktor-faktor yang mendorong terjadinya keterkaitan kota-desa serta pola pergerakan orang yang terjadi, penanganan atau solusi yang digunakan untuk meminimalisir dampak akan lebih tepat sasaran.

\section{KAJIAN PUSTAKA}

Terdapat berbagai macam faktor yang mempengaruhi keterkaitan kota-desa. Menurut hasil identifikasi faktor yang telah dilakukan oleh OECD (Organization for Economic Cooperation and Development) (2013) yang telah dimodifikasi oleh Copus (2013) menjelaskan bahwa keterkaitan kota-desa dipengaruhi oleh faktor (1) keterkaitan demografi, (2) transaksi ekonomi dan inovasi, (3) jasa/layanan publik, (4) pertukaran terkait keramahtamahan dan lingkungan, (5) keterkaitan kelembagaan. Tidak berbeda jauh dengan pernyataan dari Copus (2013), Tarigan (2003) menjelaskan bahwa untuk meningkatkan ekonomi perdesaan dengan instrumen keterkaitan kota-desa meliputi komponen (1) prasarana dan sarana sistem agribisnis, (2) pengembangan industri kecil dan rumah tangga, (3) penguatan lembaga 
dan organisasi masyarakat, (4) pengembangan jaringan produksi dan pemasaran, (5) penguasaan teknologi tepat guna, dan (6) pengelolaan sumber daya alam yang berkelanjutan.

Evans (1982) juga menjelaskan tentang faktor-faktor yang mempengaruhi keterkaitan kota-desa. Evans melihat keterkaitan (linkages) tersebut pada kasus wilayah Potosi di Bolivia dalam penelitiannya tentang UFRD (Urban Functions in Rural Development). Menurut Evans (1982) keterkaitan tersebut dipengaruhi oleh enam fungsi utama yaitu (1) transportasi: jalan dan rel kereta api, (2) produksi, (3) pasar dan perdagangan, (4) jasa layanan, (5) energi dan komunikasi, dan (6) pemerintahan.

Berlainan pada beberapa hal dengan Evans (1982), Douglass (1981) menerangkan, setidaknya ada enam faktor yang mempengaruhi keterkaitan kota-desa pada level lokal. Faktor-faktor tersebut menurut Douglass adalah (1) hubungan sosial ekonomi, (2) struktur ekonomi lokal, (3) cara produksi lokal, (4) basis sumberdaya dan lingkungan, (5) sistem spasial dan keterkaitannya, dan (6) lingkungan terbangun. lain:

Menurut Ullman dalam Daldjoeni (2003), dalam interaksi keruangan ada 3 (tiga) unsur yang saling berkaitan antara

1. Adanya komplementaritas, yang saling melengkapi sehingga akan terjadi pergerakan. Hal ini didorong adanya supply and demand. Sehingga semakin banyaknya komplementaritas semakin banyak komoditas yang terjadi.

2. Adanya transferabilitas, dimungkinkan adanya perpindahan manusia atau barang ke tempat lain, sehingga selain membutuhkan biaya juga perlu adanya peraturan di dalam pelaksanaannya, hal ini harus masuk dalam katagori transferabilitas. Sehingga semakin mudah transferabilitas semakin banyak komoditas.

3. Adanya intervening opportunity, suatu misal terjadi perang, bencana alam, huru hara hal ini akan menyebabkan pergerakan atau aktivitas terganggu, sehingga tujuannya tidak bisa tercapai dan akhirnya rencana semula gagal. Sehingga semakin sering terjadi intervening opportunity semakin kecil arus komoditas.

Menurut Lee (1979) terdapat empat faktor yang perlu diperhatikan dalam studi migrasi penduduk, yaitu: (i) faktorfaktor daerah asal; (ii) faktor-faktor yang terdapat pada daerah tujuan; (iii) rintangan-rintangan yang menghambat (rintangan antara); dan (iv) faktor-faktor individual. Disetiap daerah terdapat faktor-faktor yang menahan seseorang untuk tidak meninggalkan daerahnya atau justru menarik orang untuk pindah ke daerah tersebut. Dibandingkan dengan ketiga faktor di atas, faktor individu adalah faktor yang sangat menentukan keputusan bermigrasi. Faktor-faktor individu bukanlah faktor nyata yang terdapat di daerah asal maupun di daerah tujuan, akan tetapi ini merupakan persepsi seseorang terhadap faktor-faktor tersebut. Kepekaan pribadi, kecerdasan serta kesadaran akan kondisi tempat lain akan mempengaruhi evaluasi seseorang mengenai keadaan di daerah asal. Pengetahuan tentang tempat tujuan bergantung pada sumber informasi dan jaringan yang tersedia. Untuk sebagian orang, perlu ada alasan yang benar-benar memaksa sehingga ia mau pindah. Akan tetapi, untuk sebagian orang yang lain, sedikit dorongan saja cukup menjadi alasan baginya untuk pindah (Lee, 1979). Menurut Ravenstain (1885) dalam Grigg (1977), meskipun terdapat beragam motivasi untuk melakukan migrasi, namun alasan ekonomi selalu lebih dominan dibandingkan dengan alasan lainnya. Migrasi juga memiliki asosiasi dengan jarak,dengan tingkat migrasi antar dua titik akan berhubungan terbalik dengan jarak di antara kedua titik tersebut. Para migran yang bersedia bermigrasi jarak jauh umumnya menuju pusat-pusat industri.

Berdasarkan kajian teori di atas maka didapatkanlah faktor-faktor yang melatarbelakangi pergerakan orang dari kota ke desa ataupun sebaliknya diantaranya yaitu transaksi ekonomi, ketersediaan fasilitas, hiburan, maupun wisata. Namun demikian faktor-faktor tersebut perlu diujikan pada wilayah studi, faktor apa saja yang relevan dengan yang terjadi pada kenyataan sehari-hari di wilayah tersebut atau barangkali ada faktor tambahan lainnya. Dengan diketahuinya faktor pendorong pergerakan orang yang melatarbelakangi keterkaitan desa-kota di wilayah studi maka dapat diketahui dampak dan penanganan yang tepat untuk pengembangan wilayah pada penelitian selanjutnya.

\section{METODE PENELITIAN}

Penelitian ini merupakan penelitian campuran yaitu kualitatif dan kuantitaif, yang memiliki tujuan untuk mengetahui faktor-faktor yang mendorong terjadinya keterkaitan kota-desa dari segi pergerakan manusia. Setelah mengetahui tujuan pergerakan manusia dari desa ke kota ataupun sebaliknya, peneliti mencoba mengidentifikasi faktor-faktor yang mendasari manusia melakukan pergerakan dari kota ke desa ataupun sebaliknya. Peneliti melakukan survei dengan menggunakan kuesioner yang dibagikan kepada responden di wilayah penelitian untuk mengetahui apa faktor yang mendorong terjadinya pergerakan masyarakat kota ke desa atau sebaliknya. Untuk mendapatkan jawaban yang bervariasi, peneliti menggunakan kuesioner terbuka sehingga responden mendapatkan kebebasan dalam memberikan 
jawaban. Jadi, data yang dihimpun merupakan data kualitatif yang berasal dari pertanyaan terbuka pada kuesioner, kemudian dilakukan koding untuk penyederhanaan dan diolah menggunakan alat analisis JMP secara kuantitatif.

Lingkup masyarakat dibatasi hanya masyarakat yang bertempat tinggal di wilayah penelitian, yaitu di 3 kecamatan di Kota Mojokerto yaitu Kecamatan Prajurit Kulon, Magersari, dan Kranggan, serta 14 kecamatan yang berada di Kabupaten Mojokerto, yaitu Kecamatan Bangsal, Dlanggu, Gondang, Jatirejo, Kutorejo, Mojoanyar, Mojosari, Ngoro, Pacet, Pungging, Puri, Sooko, Trawas dan Trowulan. Dikarenakan jumlah dari orang yang melakukan pergerakan dari desa ke kota ataupun sebaliknya tidak diketahui, maka populasi pada penelitian ini dapat dikategorikan tidak terhingga atau tidak diketahui. Populasi tak terhingga yaitu populasi yang memiliki sumber data yang tidak dapat ditentukan batasbatasnya secara kuantitatif. Jumlah sampel yang diambil dalam penelitian ini menggunakan rumus Lemeshow, hal ini dikarenakan jumlah populasi tidak diketahui atau tidak terhingga. Berdasarkan rumus tersebut, didapatkan jumlah sampling sebanyak 96,04 . Namun untuk mencapai signifikansi dalam analisis pada penelitian ini, dibutuhkan responden hingga 200 orang. Sehingga peneliti menggunakan responden minimal sebanyak 200 orang.Setelah peneliti menyebarkan kuesioner yang telah dibuat, peneliti mendapatkan 211 responden dengan berbagai macam profil responden seperti pekerja, mahasiswa, dan ibu rumah tangga. Kuesioner disebarkan melalui survei online kepada penduduk responden yang berdasarkan analisis pendahuluan dapat diidentifikasi apakah tinggal di wilayah urban atau peri-urban.

Perhitungan sampel berdasarkan rumus Lemeshow adalah sebagai berikut.

$$
n=\frac{\left(Z_{\frac{\alpha}{2}}\right)^{2} \cdot p(1-p)}{e^{2}}
$$

Keterangan:

$\mathrm{n}=$ Jumlah sampel

$z=$ skor $z$ pada kepercayaan $95 \%=1,96$

$p=$ maksimal estimasi $=0,5$

$e=$ alpha $(0,10)$ atau sampling error $=10 \%$

Setelah mendapatkan hasil dari kuesioner tersebut, kemudian peneliti mengolahnya menggunakan alat analisis JMP statistic software. Peneliti membuat segmentasi pertanyaan yang berbeda untuk responden yang tinggal di wilayah kota dan responden yang tinggal di wilayah desa. Hal ini untuk memudahkan peneliti mengidentifikasi faktor yang mempengaruhi serta pertanyaan lebih tepat sasaran sehingga jawaban yang diberikan responden sesuai dengan kondisi responden. Namun sebelum diproses menggunakan JMP, perlu dilakukan pengodean pada hasil kuesioner. Pengodean dilakukan untuk mengambil kata kunci yang terdapat dalam jawaban yang diberikan responden. Pengodean dilakukan untuk mendapatkan kata kunci yang merupakan faktor-faktor pendorong masyarakat melakukan pergerakan, baik dari desa ke kota ataupun sebaliknya. Berikut adalah beberapa alasan masyarakat melakukan pergerakan yang kemudian dikerucutkan menjadi sebuah faktor dalam proses open coding. Untuk menemukan faktor-faktor yang digunakan dalam penelitian, peneliti melakukan pengelompokan alasan-alasan berpergian yang telah diberikan oleh responden pada jawaban kuesioner. Beberapa alasan-alasan tersebut telah dilakukan pengodingan pada open coding sehingga dapat lebih terkelompok. Setelah dilakukan pengelompokan, peneliti menentukan terminologi yang dapat mewakilkan alasan-alasan yang termasuk di dalamnya dan kemudian menjadi faktor-faktor yang digunakan untuk analisis klaster.

Pada faktor kemudahan akses terdapat alasan-alasan yang masuk di dalamnya adalah jarak yang dekat, akses cepat, akses mudah, mudah dijangkau, lokasi strategis, dan aksesibilitas. Alasan-alasan tersebut memiliki kemiripan/kesamaan yaitu dalam hal akses yang ada di wilayah penelitian. Sehingga peneliti kemudian menyimpulkan dan memilih terminologi kemudahan akses untuk menggambarkan alasan-alasan tersebut.

Untuk faktor rekreasi mewakilkan alasan-alasan perjalanan yang diberikan responden, yaitu refreshing, wisata, dan kondisi lingkungan yang ada di lokasi tujuan. Pada tema refreshing terdapat beberapa kata kunci yang diberikan oleh responden, antara lain mengisi waktu luang, jalan-jalan, mencari hiburan, dan nongkrong atau sekedar berkumpul bersama teman. Beberapa kata kunci tersebut memiliki kemiripan atau kesamaan, yaitu terjadi secara kebetulan dan dilakukan untuk waktu-waktu senggang dan ingin mencari hiburan. Pada tema kondisi lingkungan menggambarkan 
beberapa kondisi yang ada di lokasi tujuan yang tidak dapat ditemukan oleh reponden di tempat asal sehingga menjadi alasan responden untuk melakukan perjalanan.

Faktor relasi sosial merupakan faktor dengan alasan-alasan perjalanan yang berhubungan dengan hubungan sosial yang terjalin antara pelaku perjalanan dengan orang yang menjadi tujuan untuk melakukan perjalanan. Di dalam faktor ini terdapat alasan-alasan perjalanan antara lain yaitu berkunjung ke teman, berkunjung ke sanak keluarga, bertemu teman, dan menjenguk kerabat/sanak keluarga. Alasan-alasan perjalanan tersebut melatarbelakangi masyarakat melakukan pergerakan dan pergerakan yang terjadi cenderung hanya pada saat-saat tertentu/tidak rutin dilakukan.

Peluang usaha merupakan faktor yang erat kaitannya dengan pergerakan yang didasari karena pekerjaan. Pada faktor ini terdapat beberapa alasan perjalanan yang memiliki hubungan dengan pekerjaan pelaku pergerakan, antara lain yaitu pendapatan tinggi, lapangan pekerjaan, keuntungan lebih tinggi, hambatan dalam melakukan usaha/pekerjaan rendah, lebih mudah laku/laris, banyak segmentasi konsumen di lokasi tujuan, kondisi tempat tujuan yang ramai, lokasi strategis, terdapat banyak sasaran konsumen, serta kecenderungan karakteristik masyarakat lokasi tujuan.

Harga jual barang tinggi, harga beli barang rendah, gaji/pendapatan tinggi, serta biaya pelayanan/sarana publik yang rendah merupakan alasan-alasan perjalanan yang mendasari terbentuknya faktor biaya hidup yang rendah. Masyarakat memilih melakukan pergerakan dikarenakan di lokasi tujuan biaya yang harus dikeluarkan lebih rendah daripada di tempat asal. Sehingga hal ini yang kemudian dapat mendorong masyarakat melakukan pergerakan secara kontinu/terus-menerus guna memenuhi kebutuhannya.

Pada faktor ketersediaan fasilitas, terdapat beberapa alasan-alasan perjalanan yang masuk ke dalamnya. Alasanalasan perjalanan lebih merujuk pada jawaban responden yang berpergian dengan tujuan untuk memenuhi kebutuhan akan pelayanan fasilitas publik. Masyarakat melakukan pergerakan dikarenakan di tempat asal fasilitas yang tersedia terbatas atau bahkan tidak ada. Sedangkan di lokasi tujuan penyedia layanan fasilitas lebih beragam dan fasilitas yang tersedia lebih lengkap. Alasan-alasan berpergian yang mendasari faktor kualitas pelayanan sarana adalah kebutuhan masyarakat akan pelayanan sarana dengan kualitas yang lebih baik dari pada yang ada di tempat asal masyarakat tersebut, baik dari segi kualitas fasilitas yang tersedia, kelengkapan alat, barang dan jasa serta sistem yang berlaku sehingga mempermudah masyarakat dalam menikmati sarana.

Setelah dilakukan pengodean untuk mengerucutkan alasan pergerakan manusia menjadi beberapa faktor melalui proses open coding, kemudian dilakukan pengodean kembali yaitu dengan memberikan nilai zero-one pada masingmasing responden yang memiliki jawaban sesuai faktor yang telah ditentukan. Proses ini disebut dengan axial coding. Setelah memberikan nilai zero-one pada masing-masing responden, data hasil axial coding selanjutnya dapat diproses ke dalam alat analisis JMP.

\section{HASIL DAN PEMBAHASAN}

\subsection{FAKTOR YANG MENDORONG PERGERAKAN MANUSIA DARI DESA KE KOTA}

Hasil dari axial coding yang telah dilakukan kemudian diolah ke dalam alat analisis JMP, sehingga didapatkan hasil sebagai berikut. Pada Gambar 1 merupakan mosaic plot hasil dari analisis basic yang dilakukan untuk menguji signifikansi hasil kuesioner. Proporsi pada sumbu $\mathrm{x}$ mewakili jumlah pengamatan untuk setiap tingkat variabel $\mathrm{X}$, yaitu alasan perjalanan. Proporsi pada sumbu $Y$ di kanan mewakili proporsi keseluruhan tujuan berpergian, yaitu bekerja, sekolah/kuliah, berbelanja, berdagang, berobat,dan berkunjung. Sedangkan skala pada sumbu Y di sebelah kiri menunjukkan probabilitas pada respon hasil kuesioner, dengan seluruh sumbu menjadi suatu probabilitas yang mewakili total sampel. 


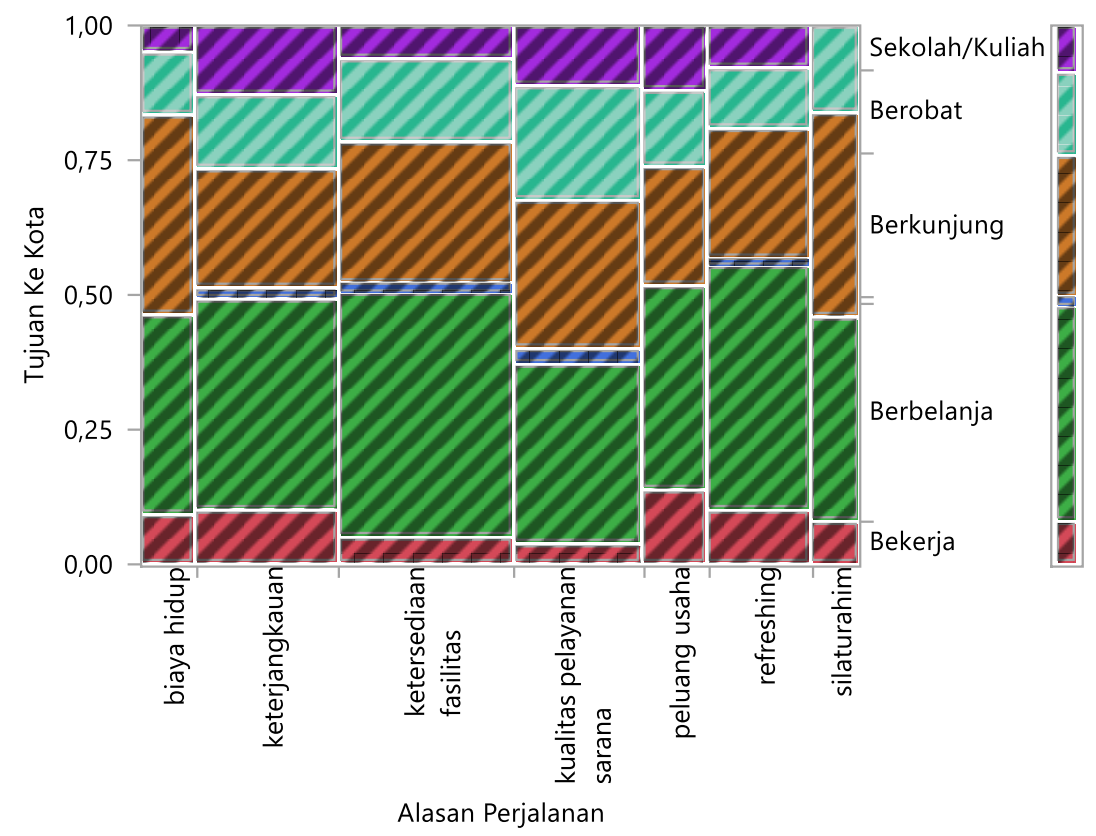

Sumber: Hasil olah JMP, 2019

Gambar 1. Mosaic Plot Analisis Kontingensi dari Tujuan ke Kota dengan Alasan Perjalanan

Pada Gambar 1 mosaic plot menunjukkan banyaknya probabilitas pada masing-masing persilangan antara sumbu $X$ (alasan perjalanan) dengan sumbu $Y$ (tujuan berpergian ke kota). Berdasarkan diagram tersebut dapat diketahui probabilitas tertinggi terdapat pada persilangan antara ketersediaan fasilitas (pada sumbu $X$ ) dengan berbelanja (pada sumbu $Y$ ) terbukti dari besaran kotak yang terbentuk dari hasil persilangan kedua sumbu tersebut. Hal ini dikarenakan di wilayah kota terdapat pusat perbelanjaan yang lebih lengkap dan beragam sehingga mendasari masyarakat desa berpergian ke kota untuk berbelanja.

Tabel 1. Kontingensi Alasan Perjalanan dengan Tujuan Ke Kota

\begin{tabular}{|c|c|c|c|c|c|c|c|}
\hline $\begin{array}{c}\text { Count } \\
\text { Total \% } \\
\text { Col \% } \\
\text { Row \% }\end{array}$ & Bekerja & Berbelanja & Berdagang & Berkunjung & Berobat & $\begin{array}{l}\text { Sekolah/ } \\
\text { Kuliah }\end{array}$ & Total \\
\hline \multirow[t]{4}{*}{ Biaya Hidup Rendah } & 8 & 32 & 0 & 32 & 10 & 4 & 86 \\
\hline & 0,73 & 2,90 & 0,00 & 2,90 & 0,91 & 0,36 & 7,80 \\
\hline & 9,09 & 7,21 & 0,00 & 10,96 & 5,95 & 4,26 & \\
\hline & 9,30 & 37,21 & 0,00 & 37,21 & 11,63 & 4,65 & \\
\hline \multirow[t]{4}{*}{ Kemudahan Akses } & 22 & 86 & 4 & 48 & 30 & 28 & 218 \\
\hline & 2,00 & 7,80 & 0,36 & 4,36 & 2,72 & 2,54 & 19,78 \\
\hline & 25,00 & 19,37 & 25,00 & 16,44 & 17,86 & 29,79 & \\
\hline & 10,09 & 39,45 & 1,83 & 22,02 & 13,76 & 12,84 & \\
\hline \multirow[t]{4}{*}{ Ketersediaan Fasilitas } & 14 & 122 & 4 & 70 & 42 & 16 & 268 \\
\hline & 1,27 & 11,07 & 0,36 & 6,35 & 3,81 & 1,45 & 24,32 \\
\hline & 15,91 & 27,48 & 25,00 & 23,97 & 25,00 & 17,02 & \\
\hline & 5,22 & 45,52 & 1,49 & 26,12 & 15,67 & 5,97 & \\
\hline Kualitas Pelayanan & 8 & 66 & 6 & 54 & 42 & 22 & 198 \\
\hline \multirow[t]{3}{*}{ Sarana } & 0,73 & 5,99 & 0,54 & 4,90 & 3,81 & 2,00 & 17,97 \\
\hline & 9,09 & 14,86 & 37,50 & 18,49 & 25,00 & 23,40 & \\
\hline & 4,04 & 33,33 & 3,03 & 27,27 & 21,21 & 11,11 & \\
\hline \multirow[t]{4}{*}{ Peluang Usaha } & 14 & 38 & 0 & 22 & 14 & 12 & 100 \\
\hline & 1,27 & 3,45 & 0,00 & 2,00 & 1,27 & 1,09 & 9,07 \\
\hline & 15,91 & 8,56 & 0,00 & 7,53 & 8,33 & 12,77 & \\
\hline & 14,00 & 38,00 & 0,00 & 22,00 & 14,00 & 12,00 & \\
\hline \multirow[t]{2}{*}{ Rekreasi } & 16 & 72 & 2 & 38 & 18 & 12 & 158 \\
\hline & 1,45 & 6,53 & 0,18 & 3,45 & 1,63 & 1,09 & 14,34 \\
\hline
\end{tabular}




\begin{tabular}{lrrrrrrr}
\hline $\begin{array}{c}\text { Count } \\
\begin{array}{c}\text { Total \% } \\
\text { Col \% } \\
\text { Row \% }\end{array}\end{array}$ & Bekerja & Berbelanja & Berdagang & Berkunjung & Berobat & $\begin{array}{c}\text { Sekolah/ } \\
\text { Kuliah }\end{array}$ & Total \\
& 18,18 & 16,22 & 12,50 & 13,01 & 10,71 & 12,77 & \\
\hline Relasi sosial & 10,13 & 45,57 & 1,27 & 24,05 & 11,39 & 7,59 & 74 \\
& 6 & 28 & 0 & 28 & 12 & 0 & 6,72 \\
& 0,54 & 2,54 & 0,00 & 2,54 & 1,09 & 0,00 & \\
\hline Total & 6,82 & 6,31 & 0,00 & 9,59 & 7,14 & 0,00 & \\
& 8,11 & 37,84 & 0,00 & 37,84 & 16,22 & 0,00 & \\
\hline
\end{tabular}

Sumber: Hasil olah JMP, 2019

Pada Tabel 1 dapat dilihat detail jumlah responden pada masing-masing persilangan antara sumbu $X$ dan $Y$. Jumlah dari masing-masing responden pada tiap perselingan dapat dilihat pada baris pertama pada masing-masing kolom. Untuk baris kedua menyatakan persentase dari responden yang menjawab alasan perjalanan dan tujuan berpergian ke kota. Pada baris ketiga pada tiap kolom meyatakan persentase dari responden yang menjawab tujuan berpergian ke kota dengan alasan perjalanan. Sedangkan pada baris keempat pada masing-masing kolom menyatakan persentase dari responden yang menjawab alasan perjalanan untuk suatu tujuan berpergian.

Tabel 2. Hasil Uji Signifikansi

\begin{tabular}{cccr}
\hline $\mathbf{N}$ & DF & -LogLike & RSquare (U) \\
\hline 1102 & 30 & 34,959287 & 0,0215 \\
\hline
\end{tabular}

\begin{tabular}{lrr}
\multicolumn{1}{c}{ Test } & ChiSquare & Prob $>$ ChiSq \\
\hline Likelihood Ratio & 69,919 & $<, 0001^{*}$ \\
Pearson & 61,768 & $0,0006^{*}$ \\
\hline
\end{tabular}

Pada Tabel 2 hasil uji signifikansi dapat dilihat pada kolom Prob > ChiSq dan baris Pearson. Pada tabel tersebut nilai signifikansi menunjukkan angka 0,0006 yang menandakan bahwa nilai tersebut mendekati 0 . Pada alat analisis JMP, angka tersebut telah menunjukkan bahwa sudah cukup signifikan dan penelitian dapat dilanjutkan.

Hierarchical Clustering menunjukkan kedekatan antara tujuan berpergian ke kota dengan alasan berpergian. Semakin dekat jarak variabel yang ditunjukkan pada Hierarchical Clustering maka semakin besar pengaruh antara dua variabel tersebut. Berdasarkan hasil dari Hierarchical Clustering yang telah dilakukan menunjukkan bahwa klaster dengan jarak paling dekat ditunjukkan pada tujuan berpergian ke kota "berbelaja" dengan alasan perjalanan "rekreasi". Untuk detail besaran jarak pada tiap klaster dapat dilihat pada Tabel 3.

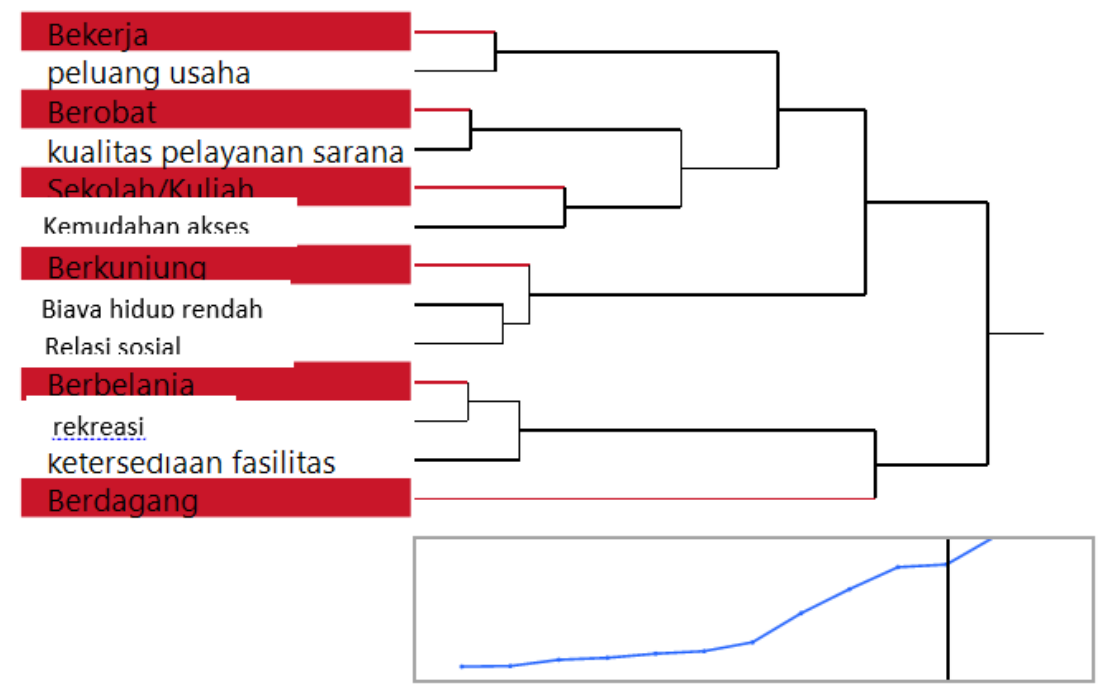

Sumber: Hasil olah JMP, 2019

Gambar 2. Dendogram Hierarchical Clustering 
Pada Gambar 2 dendogram membentuk 2 klaster. Masing-masing klaster tersebut memiliki kedekatan karakteristik. Pada klaster pertama variabel di dalamnya lebih erat dengan kualitas sarana yang ada. Sedangkan pada klaster kedua lebih erat kaitannya dengan nilai ekonomi.

Tabel 3. Clustering History Pergerakan Manusia dari Desa ke Kota

\begin{tabular}{|c|c|c|c|}
\hline $\begin{array}{c}\text { Number of } \\
\text { Clusters }\end{array}$ & Distance & Leader & Joiner \\
\hline 12 & 0,318214100 & \multirow{4}{*}{$\begin{array}{l}\text { Berbelanja } \\
\text { Berobat } \\
\text { Bekerja } \\
\text { biaya hidup } \\
\text { rendah }\end{array}$} & rekreasi \\
\hline 11 & 0,331273069 & & kualitas pelayanan sarana \\
\hline 10 & 0,479486381 & & peluang usaha \\
\hline 9 & 0,526417395 & & Relasi sosial \\
\hline 8 & 0,624919819 & Berbelanja & ketersediaan fasilitas \\
\hline 7 & 0,684568633 & Berkunjung & biaya hidup rendah \\
\hline 6 & 0,897299249 & Sekolah/Kuliah & Kemudahan akses \\
\hline 5 & 1,588502779 & Berobat & Sekolah/Kuliah \\
\hline 4 & 2,162866324 & Bekerja & Berobat \\
\hline 3 & 2,685670380 & Bekerja & Berkunjung \\
\hline 2 & 2,748516465 & Berbelanja & Berdagang \\
\hline 1 & 3,413088129 & Bekerja & Berbelanja \\
\hline
\end{tabular}

\subsection{FAKTOR YANG MENDORONG PERGERAKAN MANUSIA DARI KOTA KE DESA}

Hasil dari analisis yang dilakukan untuk mengetahui faktor yang mendorong pergerakan manusia dari kota ke desa dengan menggunakan alat analisis JMP adalah sebagai berikut.
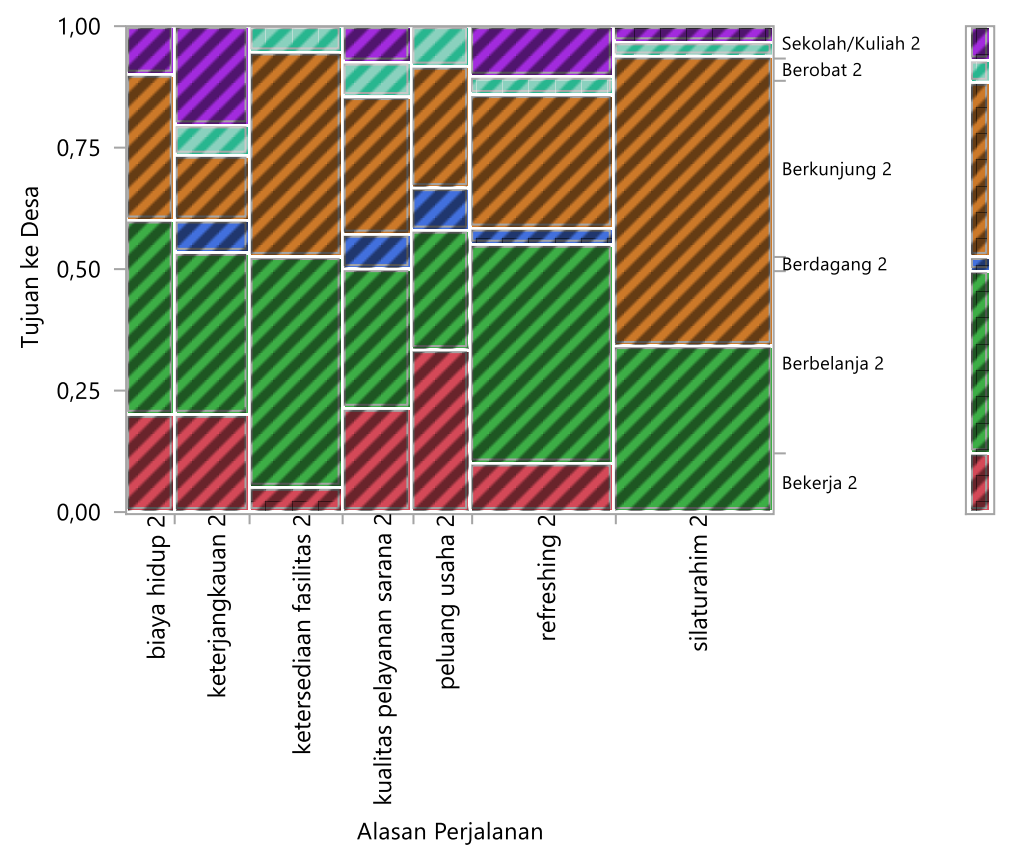

Sumber: Hasil olah JMP, 2019

Gambar 3. Mosaic Plot Analisis Kontingensi dari Tujuan ke Desa dengan Alasan Perjalanan

Sama dengan sebelumnya pada pergerakan orang dari desa ke kota, pada Mosaic Plot di atas menyatakan besaran probabilitas pada masing-masing persilangan sumbu $X$ dan $Y$. Pada kasus ini, probabilitas terbesar ditunjukkan pada persilangan antara alasan perjalanan "relasi sosial" dengan tujuan berpergian ke desa "berkunjung". Hal ini dapat dilihat berdasarkan besaran kotak yang terbentuk antara kedua sumbu tersebut (lihat Gambar 3). Jarak yang dekat antara Kota Mojokerto dengan wilayah peri-urbannya sebagai wilayah desa membuat relasi sosial antara 2 wilayah tersebut masih terjalin. Relasi sosial yang terbentuk lebih pada hubungan sanak keluarga, kerabat, dan teman. Hal tersebut tentu 
mendasari tujuan berpergian untuk berkunjung meskipun pergerakannya tidak terjadi setiap hari dan hanya pada saatsaat tertentu. Untuk detail jumlah responden dan persentase tiap jawaban responden dapat dilihat pada Tabel 4.

\begin{tabular}{|c|c|c|c|c|c|c|c|}
\hline $\begin{array}{c}\text { Count } \\
\text { Total \% } \\
\text { Col \% } \\
\text { Row \% }\end{array}$ & $\begin{array}{l}\text { Bekerja } \\
\quad 2\end{array}$ & $\begin{array}{c}\text { Berbelanja } \\
\quad 2\end{array}$ & $\begin{array}{c}\text { Berdagang } \\
2\end{array}$ & $\begin{array}{c}\text { Berkunjung } \\
2\end{array}$ & $\begin{array}{l}\text { Berobat } \\
\quad 2\end{array}$ & $\begin{array}{l}\text { Sekolah/ } \\
\text { Kuliah } 2\end{array}$ & Total \\
\hline Biaya Hidup Rendah 2 & $\begin{array}{r}4 \\
1,53 \\
12,50 \\
20,00 \\
\end{array}$ & $\begin{array}{r}8 \\
3,05 \\
8,16 \\
40,00 \\
\end{array}$ & $\begin{array}{r}0 \\
0,00 \\
0,00 \\
0,00 \\
\end{array}$ & $\begin{array}{r}6 \\
2,29 \\
6,38 \\
30,00 \\
\end{array}$ & $\begin{array}{r}0 \\
0,00 \\
0,00 \\
0,00 \\
\end{array}$ & $\begin{array}{r}2 \\
0,76 \\
11,11 \\
10,00 \\
\end{array}$ & $\begin{array}{r}20 \\
7,63\end{array}$ \\
\hline Kemudahan Akses 2 & $\begin{array}{r}6 \\
2,29 \\
18,75 \\
20,00\end{array}$ & $\begin{array}{r}10 \\
3,82 \\
10,20 \\
33,33\end{array}$ & $\begin{array}{r}2 \\
0,76 \\
25,00 \\
6,67\end{array}$ & $\begin{array}{r}4 \\
1,53 \\
4,26 \\
13,33\end{array}$ & $\begin{array}{r}2 \\
0,76 \\
16,67 \\
6,67\end{array}$ & $\begin{array}{r}6 \\
2,29 \\
33,33 \\
20,00\end{array}$ & $\begin{array}{r}30 \\
11,45\end{array}$ \\
\hline Ketersediaan Fasilitas 2 & $\begin{array}{r}2 \\
0,76 \\
6,25 \\
5,26\end{array}$ & $\begin{array}{r}18 \\
6,87 \\
18,37 \\
47,37\end{array}$ & $\begin{array}{r}0 \\
0,00 \\
0,00 \\
0,00\end{array}$ & $\begin{array}{r}16 \\
6,11 \\
17,02 \\
42,11\end{array}$ & $\begin{array}{r}2 \\
0,76 \\
16,67 \\
5,26\end{array}$ & $\begin{array}{r}0 \\
0,00 \\
0,00 \\
0,00\end{array}$ & $\begin{array}{r}38 \\
14,50\end{array}$ \\
\hline $\begin{array}{l}\text { Kualitas Pelayanan } \\
\text { Sarana } 2\end{array}$ & $\begin{array}{r}6 \\
2,29 \\
18,75 \\
21,43 \\
\end{array}$ & $\begin{array}{r}8 \\
3,05 \\
8,16 \\
28,57 \\
\end{array}$ & $\begin{array}{r}2 \\
0,76 \\
25,00 \\
7,14 \\
\end{array}$ & $\begin{array}{r}8 \\
3,05 \\
8,51 \\
28,57 \\
\end{array}$ & $\begin{array}{r}2 \\
0,76 \\
16,67 \\
7,14 \\
\end{array}$ & $\begin{array}{r}2 \\
0,76 \\
11,11 \\
7,14 \\
\end{array}$ & $\begin{array}{r}28 \\
10,69\end{array}$ \\
\hline Peluang Usaha 2 & $\begin{array}{r}8 \\
3,05 \\
25,00 \\
33,33\end{array}$ & $\begin{array}{r}6 \\
2,29 \\
6,12 \\
25,00\end{array}$ & $\begin{array}{r}2 \\
0,76 \\
25,00 \\
8,33\end{array}$ & $\begin{array}{r}6 \\
2,29 \\
6,38 \\
25,00\end{array}$ & $\begin{array}{r}2 \\
0,76 \\
16,67 \\
8,33\end{array}$ & $\begin{array}{r}0 \\
0,00 \\
0,00 \\
0,00\end{array}$ & $\begin{array}{r}24 \\
9,16\end{array}$ \\
\hline Rekreasi 2 & $\begin{array}{r}6 \\
2,29 \\
18,75 \\
10,34 \\
\end{array}$ & $\begin{array}{r}26 \\
9,92 \\
26,53 \\
44,83 \\
\end{array}$ & $\begin{array}{r}2 \\
0,76 \\
25,00 \\
3,45 \\
\end{array}$ & $\begin{array}{r}16 \\
6,11 \\
17,02 \\
27,59 \\
\end{array}$ & $\begin{array}{r}2 \\
0,76 \\
16,67 \\
3,45 \\
\end{array}$ & $\begin{array}{r}6 \\
2,29 \\
33,33 \\
10,34 \\
\end{array}$ & $\begin{array}{r}58 \\
22,14\end{array}$ \\
\hline Relasi Sosial 2 & $\begin{array}{r}0 \\
0,00 \\
0,00 \\
0,00\end{array}$ & $\begin{array}{r}22 \\
8,40 \\
22,45 \\
34,38\end{array}$ & $\begin{array}{r}0 \\
0,00 \\
0,00 \\
0,00\end{array}$ & $\begin{array}{r}38 \\
14,50 \\
40,43 \\
59,38\end{array}$ & $\begin{array}{r}2 \\
0,76 \\
16,67 \\
3,13\end{array}$ & $\begin{array}{r}2 \\
0,76 \\
11,11 \\
3,13\end{array}$ & $\begin{array}{r}64 \\
24,43\end{array}$ \\
\hline Total & $\begin{array}{r}32 \\
12,21\end{array}$ & $\begin{array}{r}98 \\
37,40\end{array}$ & $\begin{array}{r}8 \\
3,05\end{array}$ & $\begin{array}{r}94 \\
35,88\end{array}$ & $\begin{array}{r}12 \\
4,58\end{array}$ & $\begin{array}{r}18 \\
6,87\end{array}$ & 262 \\
\hline
\end{tabular}

Tabel 5. Hasil Uji Signifikansi

\begin{tabular}{rrrr}
\hline N & DF & -LogLike & RSquare (U) \\
\hline 262 & 30 & 39,459173 & 0,1058 \\
\hline
\end{tabular}

Warning: $20 \%$ of cells have expected count less than 5 , ChiSquare suspect.

\begin{tabular}{lrr}
\hline \multicolumn{1}{c}{ Test } & ChiSquare & Prob $>$ ChiSq \\
\hline Likelihood Ratio & 78,918 & $<, 0001^{*}$ \\
Pearson & 69,462 & $<, 0001^{*}$ \\
\hline
\end{tabular}

Berdasarakan nilai yang menunjukkan angka $<, 0001$ yang berarti telah mendekati 0 sehingga angka tersebut telah cukup kecil untuk menunjukkan signifikansi pada penelitan ini dan penelitian dapat dilanjutkan (lihat Tabel 5). Pada Gambar 4, dendogram menghasilkan 2 klaster dengan karakteristik yang berbeda. Klaster pertama lebih kepada tujuan masyarakat yang sifatnya sosial ekonomi. Sedangkan klaster kedua lebih kepada tujuan yang bersifat entertain/hiburan. 


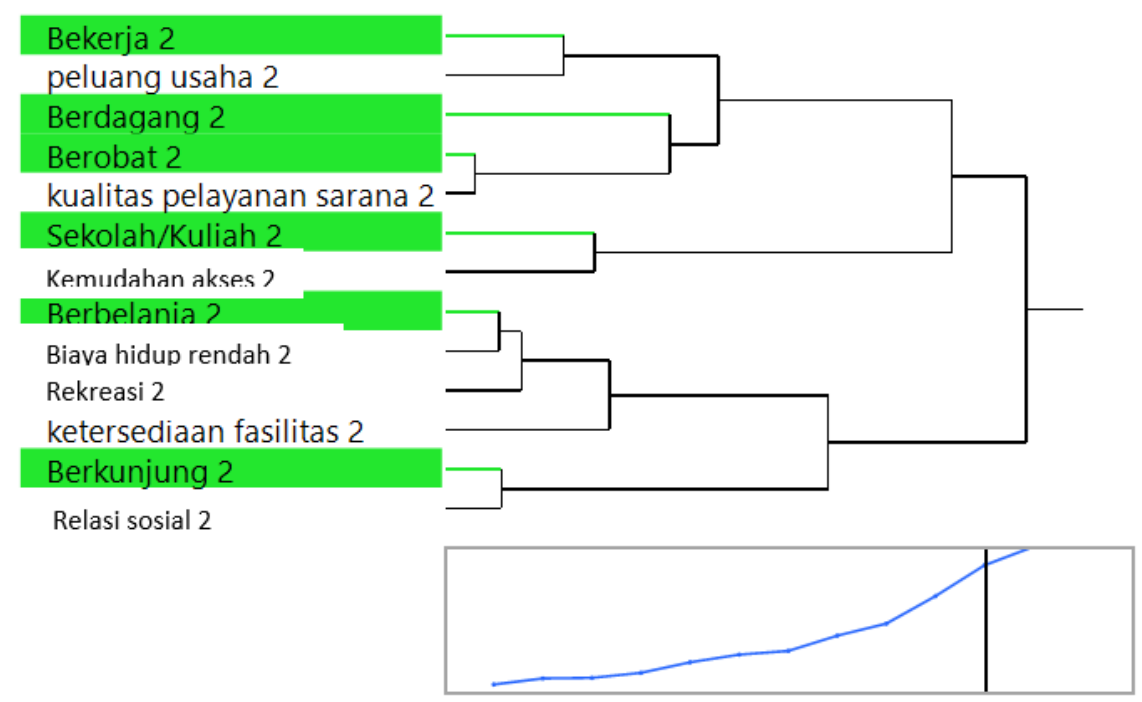

Sumber: Hasil olah JMP, 2019

Gambar 4. Dendogram Hierarchical Clustering

Tabel 6. Clustering Hierarchy Pergerakan Manusia dari Kota ke Desa

\begin{tabular}{ccll}
\hline $\begin{array}{c}\text { Number of } \\
\text { Clusters }\end{array}$ & \multicolumn{1}{c}{ Distance } & \multicolumn{1}{c}{ Leader } & \multicolumn{1}{c}{ Joiner } \\
\hline 12 & 0,181803928 & Berobat 2 & kualitas pelayanan sarana 2 \\
11 & 0,331075269 & Berbelanja 2 & biaya hidup rendah 2 \\
10 & 0,345503082 & Berkunjung 2 & Relasi sosial 2 \\
9 & 0,469578497 & Berbelanja 2 & rekreasi 2 \\
8 & 0,730837066 & Bekerja 2 & peluang usaha 2 \\
7 & 0,920366261 & Sekolah/Kuliah 2 & Kemudahan akses 2 \\
6 & 1,012674837 & Berbelanja 2 & ketersediaan fasilitas 2 \\
5 & 1,390248488 & Berdagang 2 & Berobat 2 \\
4 & 1,688427273 & Bekerja 2 & Berdagang 2 \\
3 & 2,367600293 & Berbelanja 2 & Berkunjung 2 \\
2 & 3,132671448 & Bekerja 2 & Sekolah/Kuliah 2 \\
1 & 3,592772452 & Bekerja 2 & Berbelanja 2 \\
\hline
\end{tabular}

Dari hasil analasis menggunakan alat analisis JMP, dapat disimpulkan bahwa pada masing-masing tujuan berpergian memiliki faktor pendorong sendiri sesuai dengan kedekatannya pada saat dilakukan Hierarchical Clustering. Lebih jelasnya faktor pendorong terjadinya keterkaitan kota-desa dapat dilihat pada Tabel 7.

Tabel 7. Faktor Pendorong Terjadinya Keterkaitan Kota-Desa dari Segi Pergerakan Manusia

\begin{tabular}{ll}
\hline Tujuan Berpergian & Faktor Pendorong Pergerakan Manusia \\
\hline Dari Desa Ke Kota & \\
Berbelanja & a. Keinginan masyarakat untuk mencari hiburan \\
& b. Ketersediaan fasilitas perbelanjaan atau rekreasi \\
Berobat & Kualitas pelayanan sarana \\
Bekerja & Adanya peluang usaha \\
Berkunjung & Biaya hidup yang rendah \\
Sekolah/Kuliah & Kemudahan menjangkau sarana \\
\hline Dari Kota Ke Desa & \\
Berobat & Kualitas pelayanan sarana \\
Berbelanja & a. Biaya hidup yang rendah \\
& b. Keinginan masyarakat utnuk mencari hiburan \\
Berkunjung & c. Ketersediaan fasilitas perbelajaan atau rekreasi \\
Bekerja & Adanya relasi/hubungan sosial \\
Sekolah/Kuliah & Adanya peluang usaha \\
\hline & Kemudahan menjangkau sarana \\
\hline
\end{tabular}


Berdasarkan tabel di atas, didapatkan masing-masing faktor pada setiap tujuan berpergian yang dilakukan oleh masyarakat desa maupun kota. Faktor-faktor tersebut didapatkan berdasarkan hasil dari kedekatan pada klaster-klaster yang terbentuk pada dendogram. Bentukan klaster-klaster tersebut erat kaitannya dengan frekuensi jumlah orang yang melakukan pergerakan dari desa ke kota ataupun sebaliknya. Faktor-faktor pendorong pada masing-masing tujuan berpergian juga dipengaruhi oleh preferensi masyarakat. Masyarakat cenderung melakukan pergerakan karena adanya sugesti yang berkembang di masyarakat dan berdasarkan pengalaman pribadi di masa lalu. Misal pada faktor yang terbentuk pada tujuan berpergian untuk berobat di wilayah kota dan wilayah desa yang memiliki kesamaan faktor yaitu kualitas pelayanan. Masyarakat memilih lokasi berobat berdasarkan pengalaman di masa lalu. Selain itu masyarakat juga memilih tempat berobat yang memiliki kualitas pelayanan sesuai dengan penyakit yang diderita. Hal ini karena di lokasi asal tidak terdapat pelayanan spesialis sesuai yang dibutuhkan. Berdasarkan penjelasan tersebut dapat diketahui mengapa terdapat beberapa tujuan berpergian masyarakat yang memiliki kesamaan faktor pendorong pada pergerakan masyarakat desa ke kota dan dari kota ke desa. Meski memiliki kesamaan faktor, frekuensi jumlah masyarakat yang melakukan pergerakan berbeda. Jumlah masyarakat dari desa ke kota melakukan berpergian dengan tujuan berobat lebih tinggi dibanding masyarakat dari kota ke desa. Hasil analisis klaster ini hanya menggambarkan bahwa suatu tujuan berpergian sangat erat kaitannya dengan suatu faktor dibandingkan dengan faktor-faktor lainnya.

\section{KESIMPULAN}

Berdasarkan hasil penelitian pola pergerakan orang dari desa ke kota didominasi oleh masyarakat yang bertujuan untuk berbelanja dan berkunjung ke sanak keluarga, kerabat, atau teman. Sedangkan untuk pergerakan orang dari kota ke desa lebih didominasi oleh masyarakat dengan tujuan berkunjung serta berbelanja. Terdapat beberapa faktor yang menjadi pendorong terjadinya keterkaitan kota-desa dari segi pergerakan manusia antara Kota Mojokerto dengan wilayah peri-urban. Faktor yang mendorong terjadinya pergerakan manusia dari desa ke kota antara lain sebagai berikut.

1. Keinginan masyarakat untuk mencari hiburan, merupakan faktor yang paling dominan menjadi pendorong masyarakat desa melakukan pergerakan ke kota. Hal ini juga selaras dengan tujuan masyarakat desa berpergian ke kota yang paling dominan yaitu untuk berbelanja yang mencakup membeli kebutuhan sehari-hari, rekreasi/berwisata, dan kuliner.

2. Ketersediaan fasilitas perbelanjaan atau rekreasi

3. Kualitas pelayanan sarana

4. Adanya peluang usaha

5. Biaya hidup yang rendah

6. Kemudahan menjangkau sarana

Sedangkan untuk faktor yang mendorong terjadinya pergerakan manusia dari kota ke desa antara lain sebagai berikut.

1. Kualitas pelayanan sarana, merupakan faktor yang paling memiliki pengaruh sebagai pendorong masyarakat kota berpergian ke desa.

2. Biaya hidup yang rendah

3. Keinginan masyarakat untuk mencari hiburan

4. Ketersediaan fasilitas perbelanjaan atau rekreasi

5. Adanya relasi/hubungan sosial

6. Adanya peluang usaha

7. Kemudahan menjangkau sarana

Faktor-faktor yang didapatkan tersebut juga dipengaruhi oleh profil responden yang didapatkan. Hal tersebut tentu sangat berpengaruh pada tujuan berpergian masyarakat serta alasan perjalanan yang menjadi dasar pembentukan faktor yang mempengaruhi keterkaitan kota-desa dari segi pergerakan orang antara Kota Mojokerto dengan Kabupaten Mojokerto.

Berdasarkan hasil penelitian ini, dapat disimpulkan bahwa keterkaitan kota-desa antara Kota Mojokerto dengan wilayah peri-urban di Kabupaten Mojokerto yang terjadi merupakan salah satu contoh dari hubungan timbal balik antar wilayah. Adanya tujuan berpergian masyarakat dengan maksud untuk memenuhi kebutuhan sehari-hari, baik dari segi kebutuhan pokok maupun dari segi pelayanan sarana menggambarkan hubungan yang saling mengisi (complementarity). Adanya perpindahan manusia atau barang (transferability) yang dilakukan oleh masyarakat dari desa ke kota maupun sebaliknya. Serta akibat dari faktor penghambat (intervening oppoturnity) yang berupa keterbatasan 
sumber daya dan sarana yang tersedia. Faktor-faktor yang ditemukan dalam penelitian ini termasuk ke dalam faktor hubungan sosial ekonomi yang memiliki kaitan yang erat dengan pergerakan orang. Faktor-faktor pendorong terjadinya keterkaitan kota-desa yang ditemukan dalam penelitian ini juga memiliki kaitan yang erat dengan unsur-unsur pembentuk keterkaitan seperti yang dijelaskan oleh Rondinelli (1985). Faktor-faktor tersebut menjadi pembentuk keterkaitan kota-desa, antara lain yaitu keterkaitan ekonomi, keterkaitan pergerakan penduduk, keterkaitan sosial, dan keterkaitan pelayanan sosial.

\section{DAFTAR PUSTAKA}

Braun, J, V., (2007). Rural Urban Linkages for Growth, Employment, and Poverty Reduction. Fifth International Conference on the Ethiopian Economy, United Nations Conference Center, Addis Ababa. Diakses dari https://pdfs.semanticscholar.org/c194/3092c3d0c0600061f96185fddb9599a6885d.pdf

Copus, A. (2013) Urban-Rural Relationshios in the New Century: Clarifying a Intervention Logic. New Paradigm in Action, 7, 539-552 Diakses dari https://www.researchgate.net/publication/281585899_URBAN-

RURAL_RELATIONSHIPS_IN_THE_NEW_CENTURY_CLARIFYING_AND_UPDATING_THE_INTERVENTION_LOGIC

Daldjoeni, N. (2003). Geografi Baru Organisasi Keruangan Dalam Teori dan Praktek. Bandung: PT Alumni.

Douglass, M. (1981). A Regional Network Strategy for Reciprocal Rural-Urban Linkages: An Agenda for Policy Research with Reference to Indonesia. Third World Planning Review, 20(1), 1-33. https://doi.org/10.3828/twpr.20.1.f2827602h503k5j6

Evans, Hugh. (1982). Urban Functions in Rural Development: The Case of The Potosi Region in Bolivia. US Agency for International Development, Regional and Rural Development Division, Vols. I and II. Washington, DC.

Grigg, D.B., (1977). E.G. Ravenstein and The "Laws of Migration". Journal of Historical Geography, 3(1), 41-54. https://doi.org/10.1016/0305-7488(77)90143-8

Kasikoen, K. M., (2005). Kajian Keterkaitan Perkotaan - Perdesaan di Jawa Barat. Bogor: Institut Pertanian Bogor.

Kasikoen, K. M., (2011). Keterkaitan Antar Wilayah (Studi Kasus: Kabupaten Cilacap). Jurnal Planesa, 2(2), 146-153. Diakses dari https://ejurnal.esaunggul.ac.id/index.php/planesa/article/view/548

Lee, L., (1979). Factors Affecting Land Use Change in The Rural- Urban Fringe. In Growth and Change: A Journal of Regional

Development, 10. https://doi.org/10.1111/j.1468-2257.1979.tb00861.x

Rondinelli, D. A. (1985). Applied Methods of Regional Analysis: The Spatial Dimensions of Development Policy. London: Westview Press.

Tacoli, C. (1998). Rural-Urban Interactions: A Guide to the Literature. Environmental and Urbanization, 10(1), 147-166. https://doi.org/10.1177/095624789801000105

Tarigan, Robinson. (2003). Ekonomi Regional Teori dan Aplikasi. Jakarta: PT Bumi Aksara. 